\title{
Relationships between plasma zinc and ferritin with nutritional status in thalassemic children
}

\author{
Luszy Arijanty, Sri Sudaryati Nasar, Bambang Madiyono, Djajadiman Gatot
}

\begin{abstract}
Background Repeated blood transfusions in thalassemic children can lead to iron overload in the body. High ferritin level leads to low plasma zinc status because of their competitive inhibition. Previous study found that there was a correlation between plasma zinc level and nutritional status.

Objective To obtain plasma zinc level, to investigate the correlation between plasma zinc and ferritin, and the impact of plasma zinc on nutritional status in children with thallasemia.

Methods A cross sectional study was conducted on 67 thalassemic children. This study was performed at Thalassemia Center, Cipto Mangunkusumo Hospital, Jakarta, from $1^{\text {st }}$ until $31^{\text {st }}$ of March 2005. The age of the patients ranged from 4 to 18 years, with ferritin levels more than $2000 \mathrm{ng} / \mathrm{ml}$ during the last 6 months or total transfusion more than 5 liters. The subjects were divided into 2 groups, i.e. group 1 (4-10 years) and group 2 (>10-18 years). Dietary intake was assessed by 3 day-dietary recall. The nutritional status were judged by mid upper arm circumference (MUAC) for age and height for age (H/A). Venous blood was obtained to measure plasma zinc and ferritin levels. Statistical analysis was done by Student's t-test (2-tailed) and linear regression analysis.

Results We found that $42 \%$ subjects were well-nourished, $51 \%$ were undernourished, and $7 \%$ were severely malnourished. All subjects had low plasma zinc status 31.9 (SD 16.9) $\mu \mathrm{g} / \mathrm{dl}$. There was a weak negative correlation between plasma zinc and ferritin level $(r$ $=-0.282, P=0.021$ ). Lower zinc intake was detected in 65 out of 67 subjects.

Conclusion All thalassemic children in our hospital had low plasma zinc level. There was a weak negative correlation between plasma zinc level and ferritin level. There was no significant correlation between plasma zinc status and nutritional status [Paediatr Indones 2006;46:220-224].
\end{abstract}

Keywords: zinc, ferritin, nutritional status, thalassemia.

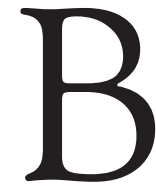

lood transfusion is still the main intervention of thalassemia. In Indonesia, desferrioxamine as a chelating agent can not be afforded by most of the patients. Those who can afford desferrioxamine use it only for several days after blood transfusion instead of standard treatment of 5 days a week. ConsequentIty most thalassemic children in our hospital have iron overload. Ferritin level more than $2000 \mu \mathrm{g} / \mathrm{ml}$ leads to haemochromatosis of many organs. ${ }^{1,2}$ High ferritin level may reflect plasma iron status in thalassemic children. Large amount of iron may decrease zinc absorption because of competitive inhibition between zinc and iron in binding site with transferin. ${ }^{3-5}$

Zinc is an essential mineral found in almost every cell in the body. It is essential to regulate enzyme systems that influence cell division and proliferation. Zinc supports immune system, helps to maintain sense of taste and smell, and is needed for wound healing and DNA synthesis; it also supports normal growth and development during childhood and adolescence. Zinc is found in a wide variety of food. Seafood, oysters, and red meat pro-

From the Department of Child Health, Medical School, University of Indonesia, Jakarta, Indonesia.

Reprint request to: Luszy Arijanty, MD, Department of Child Health, Medical School, University of Indonesia, Jl. Salemba 6, Jakarta 10430, Indonesia. Tel 62-21-3907742, Fax 62-21-3907743. 
Luszy Arijanty et al: Relationships between plasma zinc and ferritin with nutritional status in thalassemic children

vide the majority of zinc. Other good food resources include beans, nuts, whole grain, fortified breakfast cereals, and dairy products. Zinc originated from plant protein is absorbed better than from animal protein. Phytates, which are found in whole grain breads, cereal, legumes, and other products, is a strong inhibitor of zinc absorption. Tea and coffee, which consist of polyphenol, can also decrease zinc absorption. The main enhancers are ascorbic acid from fruits and vegetables. ${ }^{3,6-9}$

Many aspects of zinc deficiency have been studied. The purpose of this study is to find out plasma zinc level in thalassemic children in Cipto Mangunkusumo (CM) Hospital, Jakarta, the correlation between plasma zinc and ferritin, and the impact of plasma zinc on nutritional status.

\section{Methods}

A cross sectional study was carried out on thalassemic children who came to the outpatient clinic, Thalassemia Center, CM Hospital from $1^{\text {st }}$ until $31^{\text {st }}$ of March 2005. Inclusion criteria were thalassemic children ( $\beta$-homozygote or $\mathrm{HbE}$ with severe clinical manifestations). Their ages ranged from 4-18 years with ferritin levels of more than $2000 \mathrm{ng} / \mathrm{ml}$ during the last 6 months or total transfusion of packed red cell more than 5 liters. Informed consent was obtained from their parents. Patients with any symptoms of chronic infection or chronic diarrhea, were excluded from this study. Sample size was estimated according to the malnutrition prevalence in thalassemic children and correlation between zinc plasma level and nutritional status. The total subjects needed was 67 . Subjects were divided by their ages into 2 groups; i.e., 4-10 years old group and $>10-18$ years old group.

Zinc dietary intakes were assessed by 3-day dietary recall. The nutritional status were measured by mid upper arm circumference (MUAC) for age and height for age $(\mathrm{H} / \mathrm{A})$. Evaluation of $\mathrm{H} / \mathrm{A}$ and MUAC were derived from the reference values, using the appropriate age and sex. Venous blood was obtained from thalassemic children for determination of plasma zinc and ferritin levels. Plasma zinc level was measured by atomic absorption spectrophotometer (AAS). Plasma ferritin levels were determined by ELISA.
Statistical analysis was based on Student's t-test (2-tailed) and linear regression analysis with a level of significance $<0.05$. All statistical procedures were done on SPSS 10.00 for Windows program. The study was approved by the Committee for Medical Research Ethics of the Medical School, University of Indonesia.

\section{Results}

There were 67 subjects, 37 males and 30 females. Mean age was 9.6 (SD 3.3) years (range 4.0 to 15.6 years). Characteristics of subjects are shown in Table 1 .

We found $41.8 \%$ subjects were well-nourished, $50.7 \%$ were under-nourished, and $7.5 \%$ had severe malnutrition. Figure 1 showed higher prevalence of malnourished subjects in the second group (72\%), and higher prevalence of well-nourished subjects in the first group (53\%).

All subjects had low plasma zinc status of $31.9 \pm 16.9 \mu \mathrm{g} / \mathrm{dl}$ (range 0.6-72.9) and high plasma ferritin levels of $2855.7 \pm 848.3 \mathrm{ng} / \mathrm{ml}$ (range 1039.15035.7). Plasma zinc levels in well-nourished children was $31.5 \pm 16.7 \mu \mathrm{g} / \mathrm{dl}$ and in malnourished cases was $25.8 \pm 19.3 \mu \mathrm{g} / \mathrm{dl}$. Based on univariate analysis, there was no significant difference $(\mathrm{P}=0.86)$ in plasma zinc level between well-nourished and malnourished subjects, but there was a weak negative correlation between plasma zinc and ferritin levels $(\mathrm{P}=0.021, \mathrm{r}=$ 0.282 ). Figure 2 showed the correlation between plasma zinc and ferritin levels.

Dietary recall showed that 65 of 67 subjects had zinc dietary intake lower than recommended dietary allowances (RDA). Well-nourished subjects had $4.2 \pm 3.2 \mathrm{mg}$ zinc dietary intake/day, while under-nourished subjects had $3.4 \pm 1.5 \mathrm{mg} /$ day. There was no significant difference $(\mathrm{P}=0.21)$ in zinc dietary intake between those 2 groups.

Table 1. Characteristics of subjects

\begin{tabular}{|c|c|}
\hline Characteristics & $\begin{array}{l}\text { Total } \\
\text { n (\%) }\end{array}$ \\
\hline \multicolumn{2}{|l|}{ Sex } \\
\hline Male & 37 (55) \\
\hline Female & $30(45)$ \\
\hline \multicolumn{2}{|c|}{ Age (years) (mean $9.6 \pm 3.3$, range $4.0-15.6$ ) } \\
\hline $4-10$ & $38(57)$ \\
\hline$>10-18$ & $29(43)$ \\
\hline
\end{tabular}




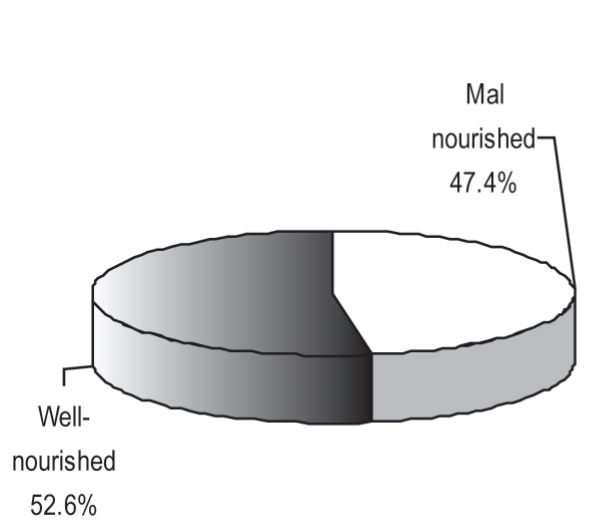

First group (4-10 years old)
Well-

nourished

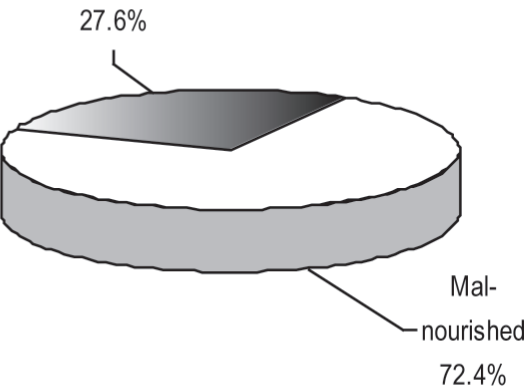

Second group (>10-18 years old)

Figure 1. Prevalence of nutritional status

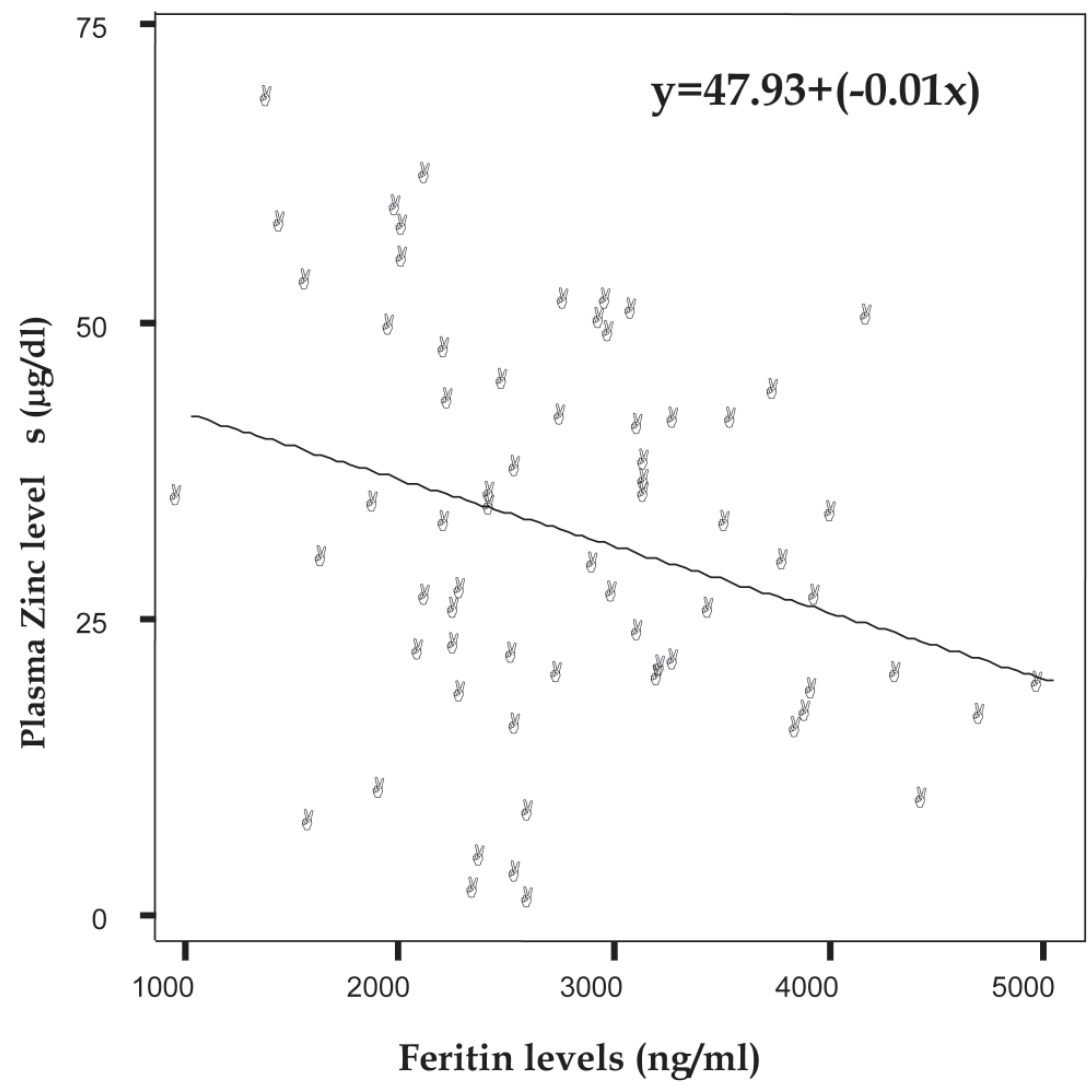

rIGURE 2. I HE CORRELATION BETWEEN PLASMA ZINC AND FERRITIN LEVELS.

Most of subjects, 42 (62.7\%) in this study were short stature (H/A less than percentile $3 \mathrm{NCHS}$ curve). Figure 3 shows that the prevalence of short stature subjects in the second group (69.0\%) was higher than in the first group (57.9\%). Plasma zinc level was slightly higher in short stature subjects than that of normal stature subjects. Based on univariate analysis, there was no significant correlation between plasma zinc level and height $(\mathrm{P}=0.66)$. 
Luszy Arijanty et al: Relationships between plasma zinc and ferritin with nutritional status in thalassemic children

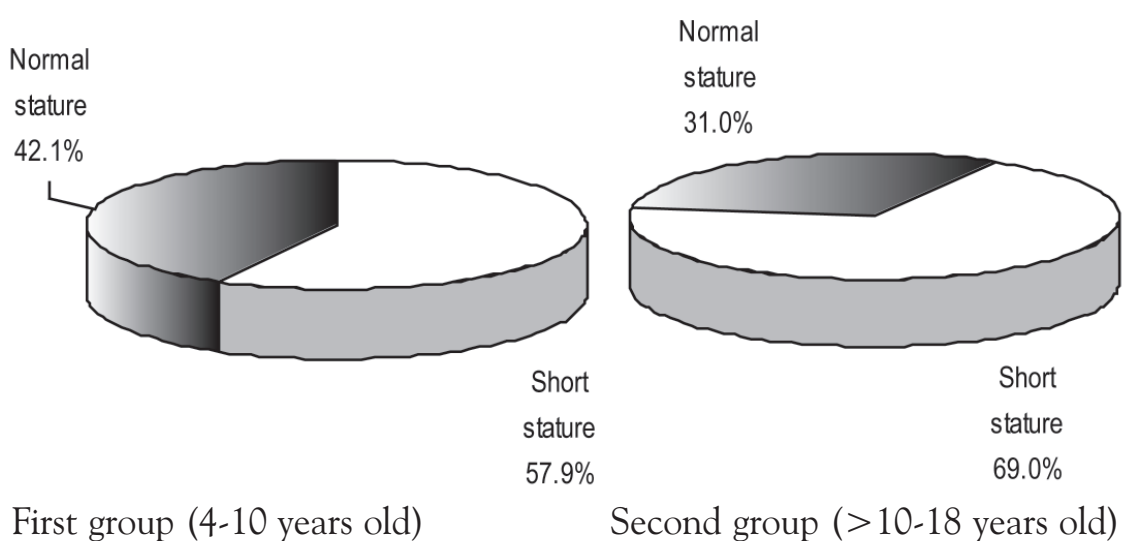

Figure 3. Height for age in thalassemic Children

\section{Discussion}

Most of the thalassemic children were undernourished $(51 \%)$, and $7.5 \%$ of them had severe malnutrition. This study showed that the prevalence of malnourished subjects in second group ( $>10-18$ years old) was higher than that of first group (4-10 years old). Wahidiyat ${ }^{1}$ reported that $64.1 \%$ of thalassemic children were undernourished, $13.2 \%$ showed severe malnutrition, and $22.7 \%$ were well-nourished. This difference presumably was caused by the difference of nutritional parameter used in both studies. Nutritional status in our study was based on MUAC for age, while Wahidiyat used weight for age.

Our study showed that all subjects (67) had low plasma zinc status of $31.9 \mu \mathrm{g} / \mathrm{dl}$. There was no significant difference $(\mathrm{P}>0.05)$ of plasma zinc level between well-nourished and malnourished subjects. On the contrary, Tanphaicitr ${ }^{10}$ concluded that zinc deficiency may be another factor affecting their nutritional status, evidenced by the significant positive correlations between plasma zinc levels with heightfor-age and MUAC $(\mathrm{P}<0.005)$. The correlation between plasma zinc level and nutritional status in our study was lower $(\mathrm{r}=0.152)$ than that reported by Tanphaicitr $(\mathrm{r}=0.41)$.

Our study found that a high ferritin value of $2855.7 \pm 848.3 \mathrm{ng} / \mathrm{ml}$ is associated with low plasma zinc level. It plays an important factor in the etiology of zinc deficiency (Figure 2). There was significant negative correlation between plasma zinc and ferritin level in this study $(\mathrm{P}=0.021, \mathrm{r}=-0.282)$. Plasma zinc sta- tus $(95 \pm 5 \mu \mathrm{g} / \mathrm{dl})$ in thalassemic children was lower than that in healthy children $(118 \pm 5 \mu \mathrm{g} / \mathrm{dl}){ }^{10}$

Virginia Stallings ${ }^{11}$ found that $44 \%$ of the children with sickle cell diseases had low plasma zinc. Those with low plasma zinc had growth abnormalities such as significant lower SD scores for height, weight, upper arm muscle area, fat-free mass, elbow breadth, and greater skeletal maturation delay. Zinc supplementation of 10-15 mg per day resulted in increased height. In older children ( $>9$ years) low plasma zinc was associated with decreased Tanner scores for pubic hair, breast, and genital maturation.

Dietary recall in this study showed that $65 \mathrm{sub}$ jects had zinc dietary intake lower than RDA. There was no correlation between zinc dietary intake and plasma zinc level. This low zinc dietary intake presumably was caused by fact that our study population consumed limited animal protein.

Dijkhuizen et al ${ }^{12}$ reported that micronutrient deficiency is still a major problem, affecting more than one half of the infants in developing countries. The prevalence of zinc deficiency in Indonesia was 24\% at 10 months of age. Sekartini et $\mathrm{al}^{13}$ found prevalence of children with zinc deficiency at elementary schools in Jakarta, Indonesia was $6.6 \%$. Fifty percent $(50 \%)$ of them had zinc dietary intake lower than RDA (2.6-3 mg/day).

In our study most of subjects, 42 subjects (62.7\%), showed short stature. Figure 3 showed higher prevalence of short stature subjects in the older group $(>10-18$ years old) than that in the younger group. The result was consistent with other studies which were reported by Wahidiyat, ${ }^{1}$ Wulandari, ${ }^{14}$ and 
Purnama Dewi. ${ }^{15}$ They found that growth disorders affected the older thalassemic children more than the younger group.

Our data demonstrated unusual facts that plasma zinc level was slightly higher in short stature subjects than that in normal stature. Based on univariate analysis, there was no significant correlation between plasma zinc level and height $(\mathrm{P}=0.66)$. There should be more subjects to prove the relationship between plasma zinc level and growth. Kattamis et allo have shown that growth of thalassemic children during the first decade largely depends on the maintenance of fairly normal $\mathrm{Hb}$ levels. This implies that hypoxia is the main factor, which causes retarded growth. This study has some limitations. Because of the difficulties to find subjects with normal zinc dietary intake based on RDA, all subjects with low zinc dietary intake were included in this study.

According to our study, all subjects (67) had low plasma zinc status. High ferritin level in thalassemic children leads to low plasma zinc level. There was a weak correlation between plasma zinc level and nutritional status.

We concluded, based on our findings, we suggest that thalassemic children with high ferritin level should increase the frequency and dose of deferoxamine, besides taking zinc supplementation. Further study is still needed with more subjects to determine the relationship between plasma zinc status and linear growth.

\section{References}

1. Wahidiyat I. Penelitian thalassemia di Jakarta [thesis]. Jakarta: Intermega; 1979.

2. Wahidiyat I. Historical perspective of thalassaemia management in Indonesia. Naskah lengkap simposium new horizon in thalassaemia control. Presented in Jakarta, June 11-12, 2002.

3. Nasar SS. Peran mikronutrien dan prebiotik pada kekebalan tubuh. Naskah lengkap simposium peranan prebiotik pada kekebalan tubuh. Presented in Jakarta June 28, 2004.

4. Almatsier S. Mineral mikro. In: Prinsip dasar ilmu gizi. 1st edition. Jakarta: PT. Gramedia Pustaka Utama; 2001. p. 249-57.

5. Boccio J, Bioch JS, Zubillaga M, Pharm LA, Caro R, Antoine J. Iron and zinc interactions evaluated between different mineral sources in different nutritional matrixes. Food and nutrition bull 2002;23: 195-8.

6. Brown KH, Wuehler SE, Peerson JM. The importance of zinc in human nutrition and estimation of the global prevalence of zinc deficiency. Food and nutrition bull 2001;22:113-22.

7. Hambidge M. Human zinc deficiency. The journal of nutrition 2000;130:1344S-9S.

8. King JC, Keen CL. Zinc. In: Modern nutrition in health and disease. 9th edition. Philadelphia: Lippincott Williams\&Wilkins; 1998. p. 223-37.

9. Hunt JR. Bioavailability of iron, zinc, and other trace minerals from vegetarian diets. Am J Clin Nutr 2003; 78:633S-9S.

10. Tanphaichitr VS, Visuthi B. Causes of inadequate protein-energy status in thalassemic children. Asia Pacific J Clin Nutr 1995;133-5.

11. Zinc deficiency in thalassemia. Available from URL: http://raredisease.info.nih.gov/html/nutrientmetabolism 05241999.html. (Cited January 10, 2004).

12. Dijkhuizen MA, Wieringa FT, West CE, Martuti S, Muhilal. Effect of iron and zinc supplemetation in Indonesian infants on micronutrient status and growth. Am Society for nutritional sciences 2001;2860-5.

13. Sekartini R, Soedjatmiko, Gunardi H, Pakasi T. Status kadar seng dan besi pada anak usia sekolah dasar di Jakarta [research]. Jakarta; 2003.

14. Wulandari HF. Gambaran radiologis tulang penderita thalassemia beta dan thalassemia beta haemoglobin $\mathrm{E}$ saat diagnosis [thesis]. Jakarta; 1999.

15. Purnama Dewi L. Profil pertumbuhan jasmani pada pasien thalassemia mayor [thesis]. Jakarta; 1993. 